\title{
CHARACTERIZATION OF WASTE BIOMASS FROM GREENHOUSE ROSE CULTIVATION AND PACKAGING
}

\author{
Giovanni Cascone, Alessandro D'Emilio, Erika Buccellato
}

\section{Introduction}

Agriculture contributes to fossil fuel consumption and, therefore, to air pollution, in a relevant way even though less than in other sectors of production. On the other hand, agriculture is strategic in the development of renewable sources of energy thanks to both the energy crops cultivations and the availability of large areas, usually not present in the urban areas, that can be utilized to host wind or solar power plants. Furthermore, all the agricultural activities produce different kinds of wastes (residual from cultivation and processing of the agricultural products, manure, etc.) usable as biomass for energy production. Biomass can be used as such or converted in solids, liquid or gaseous biofuel (pellet, biodiesel, biogas, etc.) for the production of electric power, heat or both in cogeneration.

A large number of studies focused on the characterization of various kinds of biomass for energetic purposes. Some researchers [Gray 1996; El Bassam 1998; Kalembasa 2005] concentrate on an physicchemical analysis and on the calorific value of energy crops. In another study [Todaro 2007] an evaluation of energetic characteristics of 12 indigenous tree and shrub species of Southern Italy (Basilicata Region) was carried out.

Other authors [Núñez-Regueira 2001a; NúñezRegueira 2001b] pointed out the biomass originating from forest waste, evaluating by laboratory trials the

Paper received 07.11.2009; accepted 25.05.2010

Prof. Ing. Giovanni Cascone, Full Professor. Dipartimento di Ingegneria Agraria - Sezione Costruzioni e Territorio, Università di Catania, via S. Sofia 100, 95123 Catania, gcascone@unict.it

Prof. Ing. Alessandro D'Emilio, Associate Professor. Dipartimento di Ingegneria Agraria - Sezione Costruzioni e Territorio, Università di Catania, via S. Sofia 100, 95123 Catania

Dott. Ing. ERIKA BuCCELlato, Phd. Dipartimento di Ingegneria Agraria - Sezione Costruzioni e Territorio, Università di Catania, via S. Sofia 100, 95123 Catania per.

All authors have equally partecipated in all the aspects of this pa- calorific values and the main physic and chemical properties of several hardwood forest species in Galicia (Spain).

Recently [Erol 2010] some formulae were developed for estimating the calorific values of 20 different types of biomass from their proximate analyses data.

However, no work in the literature focuses on the laboratory determination of calorific values and of physic and chemical properties of biomass originating from floriculture waste.

In Italy [ISTAT 2005] floriculture covers a surface of about 6440 ha with a production of more than 4200 millions of pieces. Specifically, Sicily is one of the most productive Italian regions with a cultivated surface of about 818 ha and a production of more than 508 millions of pieces. Among the different cut flowers produced in Italy, roses are the first for cultivated surface with about 1220 ha and the second, after carnations, for production with more than 750 millions of pieces.

The present paper aims to characterize the waste biomass originating from a soilless rose cultivation under greenhouse through the determination of some chemical and physical parameters that are meaningful for energetic processes. In detail, laboratory trials allowed the determination of both gross and net calorific values, percentage of carbon, hydrogen and nitrogen as well as moisture content, volatile content and ashes.

This work was carried out within a research aimed at the evaluation of energy consumption and at the opportunity of using renewable sources in a farm for greenhouse cultivation and packaging of roses [Buccellato 2008].

\section{Materials and methods}

The farm where the biomass was taken is located ( $36^{\circ} 57^{\prime} \mathrm{N}, 14^{\circ} 29^{\prime} \mathrm{E}$ ) in the municipal district of Vittoria, province of Ragusa, that is an area of Sicily intensely dedicated to horticulture and floriculture under greenhouse. The production is carried out inside two tunnel greenhouses with steel structures, covering a surface of about $4120 \mathrm{~m}^{2}$ and $4850 \mathrm{~m}^{2}$, respectively. 
Both the greenhouses are covered by corrugated panels: the first one is covered by polymethyl methacrylate (PMMA) panels, the second one by glass fiber reinforced polymer (GFRP) panels. Each greenhouse is equipped with an evaporative cooling plant and screening nets (shading factor 60\%). The growing system is an open soilless one, whereas the substrates used are volcanic lapillus, pumice and perlite. The substrates are not mixed together, but used separately in different benches. The farm is also provided with a plant for the packaging of the roses.

The farm produces considerable quantities of biomass that originate from the wastes due to both the cultural practices (about $3 \mathrm{t} / \mathrm{ha} /$ year) and the selection and defoliation during packaging (about $4 \mathrm{t} / \mathrm{ha} /$ year). These wastes are periodically disposed in an authorized tip.

The biomass used in this study for the laboratory trials, composed of branches and leaves of roses (about $4 \mathrm{~kg}$ ), was randomly picked from fresh waste at the end of February 2008 and exposed to open air in suitable containers for 10 consecutive sunny days in order to allow a natural reduction of its moisture content. Afterwards, the samples remained in the laboratory of the Department of Agricultural Engineering of the University of Catania until April $1^{\text {st }}$ 2008. On that date they were transferred to the laboratory of the Biomass Research Centre (CRB) of the University of Perugia where the trials were carried out.

Two kinds of samples were examined, aiming to determine the influence of the leaves on the calorific value of the biomass: the sample named C1 (fig. 1a) was made of both branches and leaves, whereas the sample named C2 (fig. 1b) was made of only branches.

The trials were carried out using the following instruments issued to the CRB laboratory:

- Heavy-duty cutting mill RETSCH SM 2000

- Elemental determinator LECO TruSpec CHN

- Thermogravimetric Analyzer LECO TGA-701

- Calorimeter LECO AC-350

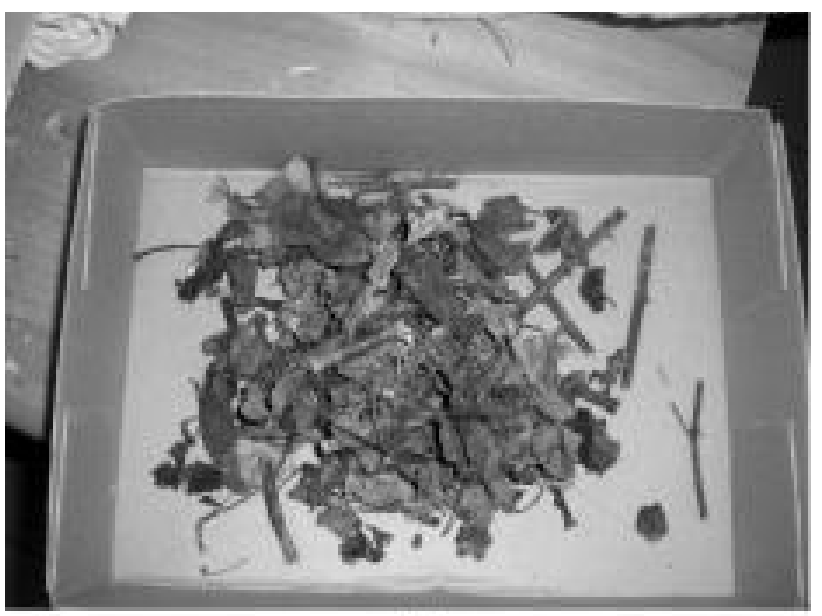

(a)
In detail, the elemental determinator was used to determine the percentage of carbon, hydrogen and nitrogen of the biomass. The thermogravimetric analyzer allowed to determine moisture content, volatile content and ashes. The calorimeter was used for the determination of the gross calorific value of the biomass.

In order to prepare the samples for the trials, the chopping of the samples was carried out using the cutting mill. A sieve with conidur holes of $1 \mathrm{~mm}$ diameter was chosen as it was judged the most suitable for the subsequent analyses with the other instruments.

All the trials with the elemental determinator were carried out according to the ASTM D5373: Standard Test Methods for Instrumental Determination of Carbon, Hydrogen, and Nitrogen in Laboratory Samples of Coal. Each trial provides that a sample of biomass, previously weighed with a precision balance (model Scaltec SBC 22), is combusted at $950^{\circ} \mathrm{C}$ in the primary furnace with a controlled atmosphere having a high content of oxygen. The products of combustion pass in a secondary furnace at $850^{\circ} \mathrm{C}$ where they are completely oxidized and separated from the particulate. The gases obtained by the combustion are collected in a container where they are homogenized and sent to two infrared detectors to measure the carbon dioxide and the water vapour from which the content of carbon and hydrogen are determined. A quantity of $3 \mathrm{cc}$ of gas is transferred to a circuit of helium flux, then to a copper catalyst for the reduction of $\mathrm{NO}_{\mathrm{x}}$ in $\mathrm{N}_{2}$, subsequently to filters for the removal of carbon dioxide and water vapour and, finally, to a thermal conductivity detector to measure the nitrogen content.

The standards used in the trials carried out by the thermogravimetric analyzer for the determination of the moisture content, ashes and volatile content were CEN/TS 14774-1:2004 (Solid biofuels - Methods for determination of moisture content - Oven dry method

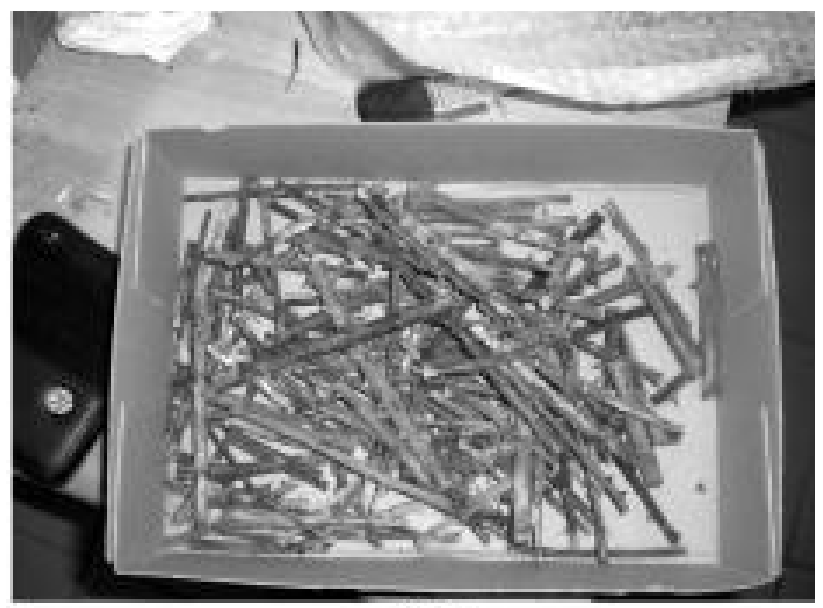

(b)

Fig. 1 - Samples of biomass before trials: (a) type C1 (branches and leaves); (b) type C2 (only branches) 
- Part 1: Total moisture - Reference method), CEN/TS 14775:2004 (Solid biofuels - Method for the determination of ash content) and ASTM D5142 (Standard Test Methods for Proximate Analysis of the Analysis Sample of Coal and Coke by Instrumental Procedures), respectively.

In a thermogravimetric analysis the weight changes of a sample in relation to temperature changes in a controlled atmosphere are continuously recorded. Subsequently, the crucibles of the instrument are loaded with the biomass, the trial starts and it develops in three steps. Firstly, the moisture content is determined. The temperature inside the instruments rises up to $105^{\circ} \mathrm{C}$ and the sample is weighed continuously by the instrument itself. The first step ends when the difference between two subsequent measures of the sample weight is lower than $5 \%$. Secondly the volatile content is measured. In this step the temperature is set at $950^{\circ} \mathrm{C}$ for a fixed time of 7 minutes. Finally the quantity of ashes is determined. The temperature varies from $350^{\circ} \mathrm{C}$ to $550^{\circ} \mathrm{C}$ and the trial ends when the difference between two subsequent measures of the sample weight is lower than $5 \%$. The instrument also calculates the percentage of the fixed carbon of the sample subtracting from the total the percentage of moisture content, volatile content and ashes.

The calorimeter LECO AC-350 allows to measure the gross calorific value of biomass using the isoperibol method according to the standards defined by ASTM, ISO, DIN and BSI. Specifically, the trials were carried out following the CEN/TS 14918/2005 (Solid Biofuels - Method for the determination of calorific value). The gross calorific value determined by the calorimeter refers to the biomass "as such" that is to the matter with its moisture content at the moment of the trial.

The procedure provides the setting of a calorimetric Mahler-bomb (fig. 2) consisting of a steel cylinder closed by an airtight screw-cap that carries the crucible, two electrodes and a valve for the inflow of oxygen. The crucible is filled with the biomass, previously weighed by the precision balance, whereas the electrodes are linked each other with a nickel wire 10 centimetres long. The Mahler-bomb is hermetically closed and filled with oxygen at 28.9 atm. Subsequently the bomb is placed into a bucket containing 2 litres of a thermostatic liquid (usually pure water). Finally, the bucket is contained inside a vessel (jacket) also containing a thermostatic liquid which temperature, being the calorimeter an isoperibol one, is kept constant throughout the whole experiment. In detail this temperature was fixed at $22^{\circ} \mathrm{C}$ that was a value always higher of the temperature of the bucket at the beginning of the trial.

Connecting the electrodes, the sample is burned increasing the temperature of the water inside the bucket. A stirrer produces turbulent motions that keep uniform the temperature of the water inside the bucket. The temperature variation of water is measured every six seconds by a Beckmann electronic thermometer

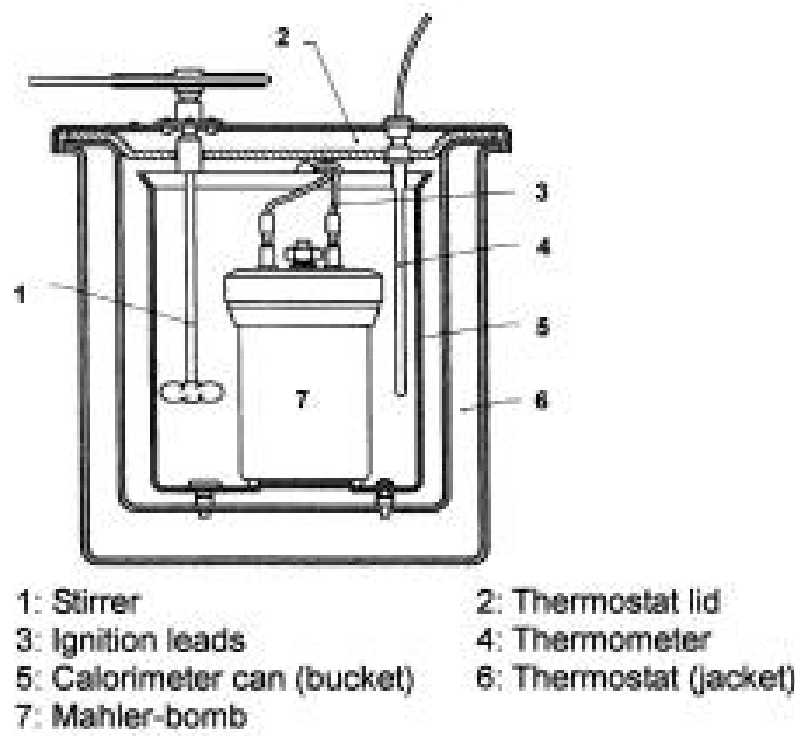

Fig. 2 - Isoperibolic calorimeter (CEN-TS 14918, 2005).

with an accuracy of $0.0001^{\circ} \mathrm{C}$. The calorific value of the biomass is determined measuring the temperature change caused by the combustion in order to calculate the heat released in the process. Due to the heat exchanges between the bucket and the jacket a correction of the temperature rise measured during the trial is required. For this aim the Regnault-Pfaundler method was adopted.

The gross calorific value obtained from the instrument must be corrected as the combustion of the nickel wire inside the Mahler-bomb must be considered subtracting the produced heat. Measuring the length of the un-burnt fragments of the wire, the length of the combusted part can be easily calculated and provided as input to the instrument that gives as output the corrected gross calorific value.

The gross calorific value, obtained for the biomass with its original moisture content, is then calculated as referred to dry biomass using the following equation:

$$
G C V_{d b}=G C V_{w e t} \times\left[\frac{100}{100-W}\right]
$$

where:

$\mathrm{GCV}_{\mathrm{db}}\left[\mathrm{Jg}^{-1}\right]$ : gross calorific value on dry basis; $\mathrm{GCV}_{\text {wet }}\left[\mathrm{Jg}^{-1}\right]$ : gross calorific value of the sample "as such", comprehensive of the nickel wire correction; $\mathrm{W}[\%]$ : percentage in weight of the moisture content of the biomass determined by the thermogravimetric analyzer.

Equations formally identical to were used to calculate the value on dry basis of each other variables measured with its original moisture content.

The most common combustion plants cannot use the water vapour produced by the fuel during combustion. Therefore the most used property for the characterization of a biomass is the net calorific value.

According to the UNI 9017 standard, the net 
calorific value was calculated with the following equation [Buratti, 2005]:

Where:

$$
N C V_{d b}=G C V_{d b}-c_{v, H_{2} O}\left(9 H_{d b}\right)
$$

$\mathrm{NCV}_{\mathrm{db}}\left[\mathrm{Jg}^{-1}\right]$ : net calorific value on dry basis;

$\mathrm{GCV}_{\mathrm{db}}\left[\mathrm{Jg}^{-1}\right]$ : gross calorific value on dry basis;

$\mathrm{c}_{\mathrm{v}}, \mathrm{H}_{2} \mathrm{O}\left[\mathrm{Jg}^{-1}\right]$ : heat of vaporization of water equal to $2397 \mathrm{Jg}^{-1}$;

$\mathrm{H}_{\mathrm{db}}[\%]$ : percentage in weight of the hydrogen contained in the sample on dry basis.

The number 9 is the approximate value of the ratio between the molecular weights of the water and of the hydrogen.

The value of $\mathrm{H}_{\mathrm{db}}$ was calculated measuring the percentage of hydrogen in the biomass "as such" $\mathrm{H}_{\text {wet }}$ through the elemental determinator and applying an equation formally identical to (1).

Each trial was carried out on three samples of both $\mathrm{C} 1$ and $\mathrm{C} 2$ biomass.

\section{Results and discussion}

The results of the laboratory trials carried out with the thermogravimetric analyzer are showed in table 1 that reports the value of the moisture content $\mathrm{W}$, of the volatile content on dry basis $\mathrm{V}_{\mathrm{db}}$ and of the ashes on dry basis $A_{d b}$ of each sample of tested biomass together with their respective mean values.

As regards the moisture content, the results of the three samples for each type of biomass are very similar, whereas the moisture content in the $\mathrm{C} 1$ biomass is slightly higher (about 5\%) than in the $\mathrm{C} 2$ biomass. The small entity of the difference in the moisture content between the two types of biomass is related to the drying they were subjected to during the 10 days of exposure to open air just after the picking.
On the contrary, the results of ash concentration show a difference of about $20 \%$ between the value measured in the $\mathrm{C} 1$ and $\mathrm{C} 2$ biomass. This result is in agreement with other authors [El Bassam, 1998; Gray, 1996; Todaro, 2007] who report for various kinds of biomass a content of ashes in leaves higher than in branches or in stems. Both the values obtained for the two type of samples are inside the wide range $(0.5 \% \div$ $12 \%)$ measured in different biomass. However, both the values are considered relatively high in a combustion process causing important dust emissions and influencing the heat exchanger design and its cleaning system [van Loo 2008].

The results of the laboratory trial carried out with the elemental determinator are showed in table 2 that reports the value of hydrogen, nitrogen and carbon content measured for each sample of tested biomass, together with their respective calculated mean values both "as such" and on dry basis.

As regards the value of hydrogen content, the results show that there is no appreciable difference between the two different types of biomass and that the values are similar to that of biomass from other plants [Kalembasa 2005].

On the contrary, the results reported in table 2 show a nitrogen content in $\mathrm{C} 1$ much higher than in $\mathrm{C} 2$ due to the presence of protein in foliage [Vidrich 1988]. In detail the difference is of $43.2 \%$ for the mean values calculated "as such" $\left(\mathrm{N}_{\text {wet }}\right)$ and rises up to $46.6 \%$ for the mean values calculated on a dry basis $\left(\mathrm{N}_{\mathrm{db}}\right)$. This result is in agreement with other studies [El Bassam, 1998] carried out with other types of vegetal biomass.

Other data [Regione Campania 2005] measured in some variety of roses from soilless cultivation on perlite and lapillus substrate report $\mathrm{N}_{\mathrm{db}}$ values equal to $1.74 \%$ for branches and to $3.51 \%$ for foliage. Assum-

\begin{tabular}{|l|c|c|c|l|c|c|c|}
\hline \multicolumn{4}{|c|}{ Biomass type C1 } & \multicolumn{5}{c|}{ Biomass type C2 } \\
\hline ID & $\mathrm{W}[\%]$ & $\mathrm{V}_{\mathrm{db}}[\%]$ & $\mathrm{A}_{\mathrm{db}}[\%]$ & $\mathrm{ID}$ & $\mathrm{W}[\%]$ & $\mathrm{V}_{\mathrm{db}}[\%]$ & $\mathrm{A}_{\mathrm{db}}[\%]$ \\
\hline Sample 1_1 & 10.75 & 80.26 & 8.35 & Sample 1_2 & 10.27 & 81.35 & 6.63 \\
\hline Sample 2_1 & 10.72 & 79.98 & 8.27 & Sample 2_2 & 10.22 & 80.98 & 6.85 \\
\hline Sample 3_1 & 10.64 & 80.63 & 8.05 & Sample 3_2 & 10.26 & 81.21 & 6.77 \\
\hline Mean & 10.70 & 80.29 & 8.22 & Mean & 10.25 & 81.18 & 6.75 \\
\hline
\end{tabular}

TABLE 1 - Moisture content $(\mathrm{W})$, volatile content $(\mathrm{V})$ and ashes $(\mathrm{A})$ of the two types of biomass obtained with the thermogravimetric analyzer.

\begin{tabular}{|l|c|c|c|l|c|c|c|}
\hline ID & $\mathrm{H}_{\mathrm{wet}}[\%]$ & $\mathrm{N}_{\mathrm{wet}}[\%]$ & $\mathrm{C}_{\mathrm{wet}}[\%]$ & $\mathrm{ID}$ & $\mathrm{H}_{\mathrm{wet}}[\%]$ & $\mathrm{N}_{\mathrm{wet}}[\%]$ & $\mathrm{C}_{\mathrm{wet}}[\%]$ \\
\hline Sample 1_1 & 6.3859 & 2.0183 & 40.925 & Sample 1_2 & 6.3601 & 1.4625 & 41.801 \\
\hline Sample 2_1 & 6.4556 & 2.2217 & 41.451 & Sample 2_2 & 6.4002 & 1.4883 & 41.347 \\
\hline Sample 3_1 & 6.4501 & 2.7331 & 41.161 & Sample 3_2 & 6.4505 & 1.9112 & 41.350 \\
\hline Mean & 6.4305 & 2.3244 & 41.179 & Mean & 6.4036 & 1.6207 & 41.499 \\
\hline & $\mathrm{H}_{\mathrm{db}}: 7.2013$ & $\mathrm{~N}_{\mathrm{db}}: 2.6030$ & $\mathrm{C}_{\mathrm{db}}: 46.113$ & & $\mathrm{H}_{\mathrm{db}}: 7.1349$ & $\mathrm{~N}_{\mathrm{db}}: 1.8058$ & $\mathrm{C}_{\mathrm{db}}: 46.238$ \\
\hline
\end{tabular}

TABLE 2 - Hydrogen $(\mathrm{H})$, nitrogen $(\mathrm{N})$ and carbon $(\mathrm{C})$ content of the two types of biomass measured "as such" and their mean value calculated on dry basis. 
ing that the $\mathrm{N}_{\mathrm{db}}$ value for a sample composed of both branches and foliage can be estimated in $2.62 \%$ obtained as the average of the respective value, it is evident the perfect agreement of the data with the results exposed in table 2. It is important to notice that even if these values are higher than the one reported for other vegetal biomass [Todaro 2007], they are consistent with roses, being the optimal concentration values of nitrogen in the foliage included in the range $3 \%$ $\div 5 \%$ [Regione Campania 2005]. Consequently, the nature of the plant imposes a nitrogen content higher than other vegetable waste currently used as biomass. The issues connected to a high content of nitrogen are related to the generation of nitrogen oxides during combustion that requires the setting of specific systems for smoke treatment.

With regards to the carbon content, table 2 shows very similar values in $\mathrm{C} 1$ and $\mathrm{C} 2$ biomass, both in agreement with the ones measured for other types of vegetal biomass [Todaro 2007].

From table 2 the calculation of the carbon to nitrogen ratio $(\mathrm{C} / \mathrm{N})$ for the $\mathrm{C} 1$ and $\mathrm{C} 2$ biomass gives 17.7 and 25.6, respectively. Therefore only the $\mathrm{C} 2$ biomass have a $\mathrm{C} / \mathrm{N}$ ratio near 30 that is the suggested threshold value for thermo-chemical processes.

The results of the laboratory trials for the measurement of the gross calorific value $\mathrm{GCV}_{\text {wet }}$, determined with the calorimeter, are reported in table 3 for the biomass samples of both the types $\mathrm{C} 1$ and $\mathrm{C} 2$, together with the weight of each sample.

The results in table 3 show that the biomass of $\mathrm{C} 2$ type has a greater $\mathrm{GCV}_{\text {wet }}$ than the $\mathrm{C} 1$ type. In detail, the mean of the $\mathrm{GCV}_{\text {wet }}$ value calculated on the results of three trials for the $\mathrm{C} 2$ type was $8.3 \%$ higher than the one of the $\mathrm{C} 1$ type, being equal to $17870 \mathrm{Jg}^{-1}$ and $16470 \mathrm{Jg}^{-1}$, respectively. This result could be related mainly to the ash content that in $\mathrm{C} 1$ type is higher than in $\mathrm{C} 2$ type, because an increase in ash content translates in a decrease of heating values [Jenkins 1998].

In order to obtain the net calorific value on dry basis $\mathrm{NCV}_{\mathrm{db}}$ it is firstly necessary to calculate the mean

\begin{tabular}{|c|c|c|}
\hline \hline \multicolumn{3}{|c|}{ Biomass: Type C1 } \\
\hline ID & $\mathrm{GCV}_{\text {wet }}\left[\mathrm{J} \cdot \mathrm{g}^{-1}\right]$ & Weight [g] \\
\hline Sample 1_1 & 16739 & 0.4050 \\
\hline Sample 2_1 & 16356 & 0.4079 \\
\hline Sample 3_1 & 16196 & 0.4377 \\
\hline Mean & 16430 & 0.4169 \\
\hline \hline \multicolumn{3}{|c|}{ Biomass: Type C2 } \\
\hline ID & $\mathrm{GCV}_{\text {wet }}\left[\mathrm{J} \cdot \mathrm{g}^{-1}\right]$ & Weight $[\mathrm{g}]$ \\
\hline Sample 1_2 & 17803 & 1.0081 \\
\hline Sample 2_2 & 17958 & 0.9263 \\
\hline Sample 3_2 & 17640 & 1.0638 \\
\hline Mean & 17801 & 0.9994 \\
\hline \hline
\end{tabular}

TABLE 3 - Gross calorific value and weight of the samples of the two types of biomass "as such" and their mean values.

\begin{tabular}{|l|c|c|}
\hline \multicolumn{1}{|c|}{ Biomass type } & $\mathrm{GCV}_{\mathrm{db}}\left[\mathrm{J} \cdot \mathrm{g}^{-1}\right]$ & $\mathrm{NCV}_{\mathrm{db}}\left[\mathrm{J} \cdot \mathrm{g}^{-1}\right]$ \\
\hline $\mathrm{C} 1$ & 18399 & 16846 \\
\hline $\mathrm{C} 2$ & 19834 & 18296 \\
\hline
\end{tabular}

TABLE 4 - Mean values of the gross calorific value of the biomass on dry basis and of net calorific value of the biomass on dry basis.

value of the gross calorific value on dry basis $\mathrm{GCV}_{\mathrm{db}}$ using (1). Subsequently, from the knowledge of the mean value of the hydrogen content, the calculation of the mean value of $\mathrm{NCV}_{\mathrm{db}}$ was performed using . The results are reported in table 4. The comparison of this table with table 3 shows that the difference between $\mathrm{GCV}_{\mathrm{db}}$ and $\mathrm{GCV}_{\text {wet }}$ for biomass type $\mathrm{C} 1$ and $\mathrm{C} 2$ is of $1969 \mathrm{Jg}^{-1}$ and $2033 \mathrm{Jg}^{-1}$, respectively. Furthermore, being the moisture content of the $\mathrm{C} 1$ and C2 biomass similar to each other, also the percentage difference in the $\mathrm{GCV}_{\mathrm{db}}$ values between the two types of biomass remains almost the same as in $\mathrm{GCV}_{\text {wet }}$ being equal to $7.8 \%$ in comparison to an $8.3 \%$.

As regards the net calorific value on dry basis $\mathrm{NCV}_{\mathrm{db}}$, the results showed in table 4 are in according to data reported in literature for other types of plants [Todaro 2007] as well as for various types of vegetable waste ranging between a value of $16500 \mathrm{Jg}^{-1}$ for biomass from pruning and of $18000 \mathrm{Jg}^{-1}$ for biomass from nurseries [Arioli 2009]. The results also show that the $\mathrm{NCV}_{\mathrm{db}}$ value of the $\mathrm{C} 2$ biomass is $8.6 \%$ higher than the $\mathrm{C} 1$ biomass.

\section{Conclusions}

Among the different cut flowers produced in Italy, roses are the first for cultivated surface with about 1220 ha. Estimating an amount of about $7 \mathrm{t} / \mathrm{ha} /$ year of waste originated from both the cultural practices during cultivation (about $3 \mathrm{t} / \mathrm{ha} / \mathrm{year}$ ) and the selection and defoliation during packaging (about $4 \mathrm{t} / \mathrm{ha} /$ year) the whole waste production can be evaluated in about 8540 t/year.

These wastes, at the same time, are a problem due to the need of their disposal and an opportunity to reduce the dependence from fossil fuels, if used as biomass for energetic purpose.

To achieve this aim, a characterization of the biomass through the determination of those chemical and physical parameters that are meaningful for energetic processes is necessary. However, no work in the literature was found on the laboratory determination of calorific values and of physic and chemical properties of waste biomass from rose cultivations.

In this paper a first contribution to the characterization of the waste biomass originating from a soilless rose cultivation under greenhouse was performed and presented. Two kinds of biomass were examined: the biomass named $\mathrm{C} 1$, made of both branches and leaves, and the biomass named $\mathrm{C} 2$, made up only of branches. 
Summarizing the results it emerges that both biomass $\mathrm{C} 1$, made of branches and foliage, and biomass $\mathrm{C} 2$, made of only branches, have a good calorific value and that the biomass $\mathrm{C} 2$ has better properties than the biomass $\mathrm{C} 1$. Indeed, the biomass $\mathrm{C} 2$, in addition to a higher net calorific value on a dry basis, also has a lower nitrogen content and a lower ash content than the biomass $\mathrm{C} 1$.

Furthermore, the biomass $\mathrm{C} 1$ has a value of $\mathrm{C} / \mathrm{N}$ ratio that is too low to be used in thermo-chemical processes. Although the biomass $\mathrm{C} 2$ has a value of $\mathrm{C} / \mathrm{N}$ ratio slightly lower than the suggested one, it could be used in thermo-chemical processes thanks to its low moisture content, provided that particular attention is paid to the design of the $\mathrm{NO}_{\mathrm{x}}$ reduction system.

\section{Acknowledgments}

The authors would like to express their grateful thanks to Prof. Francesco Asdrubali and Prof. Cinzia Buratti of the University of Perugia for having made possible the laboratory trials in the Biomass Research Centre (CRB) of the University of Perugia and to Eng. Marco Barbanera and Eng. Mattia Faleri for the technical support offered during the trials.

\section{References}

Arioli A., Guida per investire nella pirogassificazione, L'informatore Agrario, 2009, 5 (Supplemento), 29-33.

ASTM D5142. Standard Test Methods for Proximate Analysis of the Analysis Sample of Coal and Coke by Instrumental Procedures, 2004.

ASTM D5373. Standard Test Methods for Instrumental Determination of Carbon, Hydrogen, and Nitrogen in Laboratory Samples of Coal, 2008.

Buccellato E., Audit energetico e potenzialità di impiego di fonti di energia alternative in un'azienda per la produzione di rose sotto serra. PhD dissertation, 2008, Department of Agricultural Engineering, University of Catania.

Buratti C., Costarelli I., Cotana F., Crisostomi L., Fantozzi F., The Biomass Research Centre Laboratory for Biomass Characterization. Proceedings of 14th European Biomass Conference and Exhibition. Biomass for Energy, Industry and Climate Protection. Paris, 17-21 October 2005 .

CEN/TS 14774-1. Solid biofuels - Methods for determination of moisture content - Oven dry method - Part 1: Total moisture - Reference method, 2004.

CEN/TS 14775. Solid biofuels - Method for the determination of ash content, 2004.

CEN/TS 14918. Solid Biofuels - Method for the determination of calorific value, 2005.
El Bassam N., Energy Plant Species - Their use and impact on environment, James and James, 1998, London.

Erol M., Haykiri-Acma H., Kucukbayrak S., Calorific value estimation of biomass from their proximate analyses data, Renewable Energy, 2010, 35 (1), 170-173.

Gray A., Anderson C., Koppelman E., Bjornsen B., Frank K., Siedell M., Alfalfa stems: Potential biofuel for woodstoves. In: J. Janick (ed.), Progress in new crops, 260-262. ASHS Press, 1996, Alexandria (USA).

Jenkins B.M., Baxter L.L., Miles Jr T.R., Miles T.R., Combustion properties of biomass. Fuel Processing Technologies, 1998, 54, 17-46.

Kalembasa D., Jeżowski S., Pude R., Malinowska E., The content of carbon, hydrogen and nitrogen in different development stage of some clones of Miscanthus. Polish Journal of Soil Science, 2005, 38 (2), 169-177.

Núñez-Regueira L., Rodriguez-Añón J., Proupín-Castiñeiras J., Romero-Garcia A., Energetic evaluation of biomass originating from forest waste by bomb calorimetry. Journal of Thermal Analysis and Calorimetry, 2001, 66, 281292.

Núñez-Regueira L., Rodriguez-Añón J., Proupín-Castiñeiras J., Vilanova-Diz A., Montero-Santoveña N., Determination of calorific values of forest waste biomass by static bomb calorimetry. Thermochimica Acta, 2001, 371, 23-31.

Regione Campania. Centri florovivaistici di formazione e orientamento alle imprese in Campania. Attività del triennio 2003-2005, Regione Campania, Università degli Studi di Napoli Federico II, CON.FLO.MER, ISAGRU, 2005.

Todaro L., Scopa A., De Franchi A.S., Caratterizzazione energetica di biomasse agro-forestali presenti in aree collinari e montane della Basilicata. Forest@, 2007, 4, 42-50.

UNI 9017. Legno da ardere - Determinazione delle caratteristiche energetiche, 1987.

Van Loo S., Koppejan J., The handbook of biomass combustion and co-firing, Earthscan, 2008, London.

Vidrich V., Il Legno ed i suoi impieghi chimici. Edagricole, 1988, Bologna.

\section{SUMMARY}

In this work a characterization of the waste biomass originating from a rose cultivation under greenhouse was carried out. Two types of biomass were examined: one made of both branches and leaves, and the other made up only of branches. For each type of biomass the following properties were determined: percentage of carbon, hydrogen and nitrogen, content of moisture, volatile matter and ashes, gross and net calorific value. The results show that the biomass made of only branches has a better quality than the biomass with leaves for use in thermo-chemical processes.

Keywords: Calorific value, renewable sources, vegetable biomass. 